\title{
A Coluna Prestes: uma proposta de trabalho
}

\section{Anita Leocádia Prestes}

Pós-graduando em Hisotria Social - FFLCH/USP

\section{Introdução}

O fenômeno do Tenentismo, da mesma forma que o movimento de 30 , ou a assim chamada Revolução de 30 - estes em geral entendidos como o principal desdobramento e a mais importante consequiência daquele conta com uma vasta produção historiográfica. Contudo, o exame cuidado. so dessa historiografia levou-nos à constatação de um fato extremamente evidente: a ausência quase total de um acontecimento da envergadura da Coluna Prestes naquilo que nos acostumamos a considerar a História do Brasil.

Assim, a principal obra sobre o assunto, o diário da Coluna, feito pelo seu secretário, o bacharel Lourenço Moreira Lima (1), durante anos a fio esteve esgotada e ficou praticamente desconhecida de várias gerações. Publicado em 1928, este livro viu sua segunda edição apenas em 1945, só sendo reeditado recentemente, 34 anos mais tarde, em 1979. O livro de S. Dias Ferreira (com a colaboração de Sady Vale Machado), A Marcha da Couna Prestes, publicado em 1928 (2), e o terceiro voume de A Guisa de Depoimento Sobre a Revolução Brasileira de 1924, de Juarez Távora, que veio à luz também em 1928 (3) - obras importantes na historiografia da Coluna Prestes - , estão esgotados há muitos anos, sem nunca terem sido reeditados, permanecendo desconhecidos do grande público.

E interessante observar ainda a ausência quase total de qualquer contribuição efetiva dos participantes da própria Coluna, em particular de seus comandantes, para o conhecimento e compreensão desa página de nossa

(1) - Moreira Lima, Lourenço. A Coluna Prestes (Marchas e Combates). 3. ed. São Paulo, Alfa-Omega, 1979.

(2) - Ferreira, S. Dias (e Sady Valle Machado). A Marcha da Coluna Prestes. Pelotas, Livraria Globo, 1928.

(3) - Távora, Juarez. Á Guisa de Depoimento sobre a Revolução Brasileira de 1924. 3. volume. Rio de Janeiro, Machado e C., 1928. 
História. A exceção do volume já citado de Juarez Távora, sua obra posterior (4) é praticamente omissa sobre o assunto, o mesmo acontecendo com o depoimento de Osvaldo Cordeiro de Farias (5), publicado somente em 1981. Quanto ao livro de João Alberto Lins de Barros, Memórias de um Revolucionário (6), que ficou restrito apenas ao primeiro volume, limita-se também à narrativa bastante rápida e superficial de alguns episódios da Marcha da Coluna, sem revelar seu autor a preocupação com o estudo desse acontecimento ímpar da vida social e política do país.

Paradoxalmente, a pobreza da contribuição para nossa historiografia de alguns dos principais protagonistas da Coluna contrasta com as possibilidades de que dispuseram, a partir de 1930, para patrocinar e incentivar a pesquisa e o estudo desse episódio. Basta dizer que Juarez Távora, Osvaldo Cordeiro de Farias e João Alberto Lins de Barros estiveram durante anos no poder e gozaram de grande influência e prestígio por largos períodos de suas vidas. Se tivessem revelado interesse, poderiam ter contribuído decisivamente para que a Coluna Prestes fosse amplamente estudada e contasse hoje com uma vasta historiografia. A propósito, é oportuno lembrar que, como é registrado por Lourenço Moreira Lima (7) e confirmado por Luiz Carlos Prestes, todo o arquivo da Coluna, recolhido durante a Marcha desde o Rio Grande do Sul até o Ceará, foi entregue à família Távora quando da passagem da Coluna por este estado. Entretanto, não se tem conhecimento de que algum pesquisador desse período da História do Brasil tenha tido acesso a tão precioso acervo.

No que diz respeito à contribuição dos historiadores e pesquisadores de diversas áreas das Ciências Sociais, também é ela extremamente precária em relação à Coluna Prestes, como será visto adiante, no item referente à discussão historiográfica. Assim, o "brazilianista" Neill Macaulay, ao escrever todo um livro intitulado $A$ Coluna Prestes (8), limita-se a reproduzir trechos da bibliografia disponível, sem recorrer à pesquisa original, nem pretender chegar a uma interpretação histórica, o que é reconhecido pelo próprio autor.

Fica evidente que a ausência quase completa da Coluna Prestes de nossa historiografia (enquanto os levantes de 22 no Rio, 24 em São Paulo e a Revolução de 30 contam com uma vasta bibliografia) não pode ser

(4) - Távora, Juarez. Uma Vida e Muitas Lutas - Memórias. 1. volume - Da Planície à Borda do Altiplano. Rio de Janeiro, Livr. José Olympio, 1973. 2.0 volume - A Caminhada no Altiplano. Rio de Janeiro, Llvr. José Olympio, 1974. 3. volume - Voltando à Planície. Rio de Janeiro, Biblioteca do Exército, 1977.

(5) - Farias, Osvaldo Cordeiro de. Meio Século de Combate: Diálogo com Cordeiro de Farias .(Aspásia e Walder de Góes). Rio de Janeiro, Nova Fronteira, 1981.

(6) - Lins de Barros, João Roberto. Memórias de um Revolucionário. 1." parte:

A Marcha da Coluna. Rio de Janeiro, Ed. Civilização Brasileira, 1953.

(7) - Moreira Lima, obra citada, pg. 241.

(8) - Macaulay, Neill. A Coluna Prestes. São Paulo, Difel, 1977. 
aceita como um fato casual e fortuito. Principalmente, quando algumas das principais figuras da Marcha da Coluna permaneceram, durante anos, em posições de destaque na vida nacional. E impossível negar que houve o propósito deliberado de relegar a Coluna e seus feitos ao esquecimento e, ao mesmo tempo, permitir que seu conteúdo fosse esvaziado do seu verdadeiro sentido, deturpado e manipulado pelas classes dominantes ao longo dos anos que se seguiram ao movimento de 30 .

Indiscutivelmente, a ruptura de Prestes com os "tenentes" e sua adesão aos ideais comunistas podem explicar muita coisa. A partir desse momento, praticamente todos seus antigos companheiros viram-lhe as costas e aderem, em maior ou menor grau, à chamada Revolução de 30 e ao novo poder instalado sob a liderança de Getúlio Vargas. Entrementes, falar na Coluna e nos seus feitos era impossível sem referir-se a Prestes e seu papel destacado. A Coluna estava identificada com Prestes. E Prestes, a partir de 30, estava identificado com o comunismo e a União Soviética. Para as classes dominantes e seus mais novos colaboradores - os antigos "tenentes" era indispensável destruir o mito do "Cavaleiro da Esperança", que haviam ajudado a difundir, enquanto correspondia aos seus interesses.

As idéias comunistas encontravam no Brasil uma nova e original forma de propagação: por intermédio de Luiz Carlos Prestes - indiscutivelmente a figura de maior destaque e a principal liderança do movimento tenentista - poderiam atingir setores, como de fato aconteceu em certa medida, que o débil PCB (Partido Comunista Brasileiro) não tinha possibilidade de influenciar. Tratava-se, pois, para os vitoriosos de 1930, de travar o combate sem tréguas contra o comunismo e contra Prestes. Para isso, era preciso silenciar a história da Coluna e, pouco a pouco, ir transfigurando o seu verdadeiro sentido. Com o tempo, não só o sentido da Coluna seria deturpado, como o do movimento tenentista em geral. Uma outra "história" deveria aparecer, a história dos donos do poder.

Tratava-se de esquecer a verdadeira história da Coluna: uma história de luta revolucionária contra as oligarquias personificadas pelo seu representante máximo na época - o presidente Artur Bernardes; uma história de rebeldia, da qual participaram não só os "tenentes", como contingentes mais ou menos numerosos de homens e mulheres oriundos do povo, das massas populares; uma história em que, diferentemente dos estereótipos insistentemente propagados no Brasil pelas classes dominantes, verificava-se que o povo, quando encontra condições propícias, quando dispõe de lideranças em que confia e que se mostram capazes de mobilizá-lo e quando é motivado por um determinado objetivo, é capaz de organizar-se e lutar, inclusive de armas na mão, com infinita abnegação e desprendimento, pela causa abraçada.

A Coluna Prestes passara a ser perigosa não só por que seu principal comandante e líder de incontrastável prestígio nacional se tornara comu- 
nista, como também por que constituía um exemplo vivo de luta revolucionária que as classes dominantes não haviam conseguido derrotar, apesar de toda a superioridade militar e logística. Pela primeira vez na História do Brasil, um movimento revolucionário conseguira não ser derrotado pelo Governo. A Coluna partira para o exílio organizada, consciente de que cumprira com seu dever. Não se rendera, nem debandara, como queria o inimigo poderoso, que mobilizara todos os recursos, durante dois anos e meio, para liquidar com os soldados de Prestes.

A verdadeira história da Coluna passava a ser deliberadamente "esquecida", assim como o passado tenentista de seu líder máximo, que seria apresentado, a partir de então, como o grande traidor da pátria, porque aderira ao ideal comunista, em busca de uma efetiva emancipação econômica, social e política para o povo brasileiro. E o tenentismo, esvaziado do seu conteúdo de luta contra os donos do poder - as oligarquias então dominantes - , transformar-se-ia em bandeira dos militares reacionários de todos os períodos históricos que se seguiram a 1930. O ponto culminante desse processo de transfiguração da História teria lugar com o golpe de 1964. Os golpistas se intitularam "revolucionários", autoproclamando-se continuadores dos ideais de 22,24 e 30 . Isto foi repetido continuadamente nestes últimos vinte anos: a 26 de maio de 1964, o então ministro da Guerra, general Arthur Costa e Silva, o dizia explicitamente (9), da mesma maneira como ainda há pouco, o ministro da Marinha, Maximiano da Fonseca, citava numa de suas ordens-do-dia uma frase célebre de Antônio Siqueira Campos, para em seguida reafirmar a suposta continuidade do "processo revolucionário".

E, exemplo revelador dessa deturpação histórica, de que estamos falando, é a obra volumosa do jornalista Glauco Carneiro (assessor do ex"tenente" Juracy Magalhães, quando este, após o golpe de 1964, ocupou o posto de ministro do Exterior). Este autor publicou uma biografia de Siqueira Campos, em que, falseando a História, faz uma suposta exaltação da figura do herói do Forte de Copacabana para, na realidade, deformá-la, na tentativa de assim conseguir diminuir o papel de Prestes e, principalmente, deturpar o sentido do tenentismo e da Coluna. Termina por chegar à conclusão de que a Revolução de 30 só pôde ser completada em 64, acrescentando: “... a Revolução de 31 de março de 1964, que fez ascender homens e idéias tenentistas ao Poder, atrasou-se três décadas no tempo graças à morte de um único homem, justamente Siqueira Campos". (10)

Fica evidente que à verdadeira pesquisa histórica cabe resgatar a história da Coluna, o seu real conteúdo e sentido.

(9) - Ver O Estado de São Paulo, 28 de maio de 1964, pp. 7-8.

(10) - Carneiro, Glauco. O Revolucionário Siqueira Campos. 2 volumes. Rio de Janeiro, Record, 1966, pp. 30-31. 


\section{Considerações sobre a historiografia referente ao tema.}

Como já foi assinalado, a principal obra dedicada à Coluna Prestes é o diário da Marcha de Lourenço Moreira Lima (11). Em seguida, têm real importância, como fontes de informação sobre o assunto, o livro de S. Dias Ferreira, o volume III de $\dot{A}$ Guisa de Depoimento Sobre a Revolução Brasileira de 1924, de Juarez Távora e, em menor medida, o livro de João Alberto Lins de Barros, assim como os de Italo Landucci, Abguar Bastos e o livro-depoimento de Osvaldo Cordeiro de Farias.-(12) Como fontes primárias, são interessantes os depoimentos de participantes da Coluna, recolhidos pelo CPDOC (Centro de Pesquisa e Documentação de História Contemporânea do Brasil) da Fundação Getúlio Vargas: as entrevistas com Aristides Leal, Emygdio da Costa Miranda, Sady Valle Machado e Rubens Fortes. Todas estas fontes têm um caráter marcadamente descritivo, sem dúvida de valor fundamental para a pesquisa histórica, mas falta-lhes a análise, a interpretação dos acontecimentos, sem a qual não há História.

Na obra de autores como Hélio Silva, Edgar Carone, Nelson Werneck Sodré e Neill Macaulay (13) há muitos elementos para o estudo do tema. Entretanto, caracterizam-se também por seu caráter no fundamental descritivo, sendo que basicamente se apóiam nas fontes primárias acima citadas.

São de grande valor para a pesquisa do tema em questão os livros do general Bertoldo Klinger (14), que comandou os combates à Coluna nos estados de Mato Grosso e Goiás. Sua competência profissional e objetivi-

(11) - Moreira Lima, Lourenço, obra citada.

(12) - Ferreira, S. Dias, obra citada. Távora, Juarez. À Guisa de Depoimento sobre a Revolução Brasileira de 1924. 3. volume, obra citada; Lins de Barros João Alberto, obra citada; Landucci, 1talo. Cenas e Episódios da Revolução de 1924 e da Coluna Prestes. 2. ed. São Paulo, Brasiliense, 1952; Bastos, Abguar. Prestes e a Revolução Social. (Fatos políticos, condições sociais e causas econômicas de uma fase revolucionária do Brasil.) Rio de Janeiro, Ed. Calvino, 1946; Farias, Osvaldo Cordeiro de, obra citada.

(13) - Silva, Hélio. 1922: Sangue na Areia de Copacabana. (O Ciclo de Vargas - Vol. I). 2." ed. Rio de Janeiro, Civilização Brasileira, 1971; 1926: A Grande Marcha. (O ciclo de Vargas - Vol. II). 2. ${ }^{a}$ ed. Rio de Janeiro, Civilização Brasileira, 1971; 1930: A Revolução Traida. (O ciclo de Vargas - Vol. III). Rio de Janeiro, Civilização Brasileira, 1966. Carone, Edgar. Revoluções do Brasil Contemporâneo. 2. ed. São Paulo, Difel, 1975; A República Velha. I. (Instituições e Classes Sociais), 4." ed. São Paulo, Difel, 1978; A República Velha. II. Evolução Politica (1889-1930), 3. ed. São Paulo, Difel, 1977; Sodré, Nelson Werneck. A Coluna Prestes. Análise e Depoimentos. Rio de Janeiro, Civilização Brasileira, 1978; História Militar do Brasil. 2. ${ }^{2}$ ed. Rio de Janeiro, Civilização Brasileira, 1968. Macaulay, Neill, obra citada.

(14) - Klinger, Bertoldo. Narrativas Autobiográficas. Vol. III - Tempo Quente de Major. Rio de Janeiro, Ed. O Cruzeiro. 1948; Vol. IV - 380 Léguas de Cam+ panha em 3 Meses. Rio de Janeiro, Ed. O Cruzeiro, 1949; Parada e Desfile de Uma Vida de Voluntário do Brasil (na primeira metade do século). Rio de Janeiro, Ẽipresa Gráfica "O Cruzeiro", 1958. 
dade no julgamento dos fatos tornaram sua narrativa, assim como suas opiniōes - extremamente críticas em relação ao comportamento do Governo face aos revolucionários - , de valor inestimável para o estudo da Coluna Prestes. Isto é reconhecido pelo próprio Luiz Carlos Prestes em depoimento gravado que nos foi concedido.

Outros livros e depoimentos de chefes militares se inserem na historiografia relativa ao tema. Destacamos as memórias do general Rondon (15), militar que comandou as tropas que combateram os revolucionários de 24 no Paraná, a obra do coronel Paulo René de Andrade (16) sobre a Polícia Mineira, que integrou as tropas legalistas que lutaram tanto contra os revoltosos de 5 de julho de 24 em São Paulo, como contra os soldados da Coluna. Estão incluídos nesse conjunto os livros do general Abílio de Noronha (17) e a biografia do general Tasso Fragoso, de autoria de Alencar Araripe (18).

Do exame dessa literatura produzida por oficiais legalistas decorrem algumas observações importantes: a flagrante incompetência governista e o total despreparo das Forças Armadas para dar combate aos revolucionários tanto no levante de São Paulo, como, principalmente, frente à "guerra de movimento" desenvolvida pela Coluna Prestes; o fato de o Exército estar bastante minado pelos ideais tenentistas, que contavam com grande simpatia em suas fileiras; e, decorrência disto, o papel destacado das polícias estaduais e dos cangaceiros e capangas a serviço dos "coronéis" do interior na repressão e perseguição movida pelo Governo contra os revolucionários.

Quanto às interpretações do Tenentismo propriamente dito, podem ser apontadas três correntes principais. A primeira, a mais tradicional e amplamente difundida, explica o Tenentismo como um movimento que, a partir de suas origens sociais nas classes (ou camadas) médias urbanas, por vezes denominadas de pequena burguesia urbana, representaria os anseios dessas camadas por uma maior participação na vida nacional e nas instituições políticas. Sem dúvida, há matizes e diferenças entre os numerosos defensores desta tese principal, mas o que os unifica é a convicção de que o fator determinante do comportamento político dos "tenentes" residiria

(15) - Viveiros, Esther de. Rondon Conta Sua Vida. Rio de Janeiro, Livr. São José, 1958.

(16) - Andrade, Paulo René de. Três Revoluções (A Atuaçāo da Polícia Militar de Minas Gerais, a Antiga Força Pública, nos Movimentos Revolucionários de 1924, 1930 e 1932). $10^{\circ}$ volume. Belo Horizonte, Imprensa Oficial, 1976; $20^{\circ}$ volume. Belo Horizonte, Imprensa Oficial, 1978.

(17) - Noronha, Abílio de. Narrando a Verdade. Contribuição para a História da Revolta em São Paulo. São Paulo, 1924; O Resto da Verdade (Contribuição para a História da Revolta em São Paulo). São Paulo, Empresa Ed. Rochéa, 1925.

(18) - Alencar Araripe, Tristão de. Tasso Fragoso. Um Pouco de História de Nosso Exército. Rio de Janeiro, Ed. Biblioteca do Exército, 1960. 
em sua origem social pequeno-burguesa. $\mathrm{O}$ Tenentismo seria a expressão da revolta da pequena burguesia urbana contra as oligarquias. Como diz Virgínio Santa Rosa, provavelmente o pioneiro desta interpretação, os "tenentes" e o tenentismo seriam a força que impulsionava "o movimento ascensional da pequena burguesia". (19)

Já Nelson Werneck Sodré considera que "o reformismo tenentista é expressão política da pequena burguesia brasileira, vanguarda aguerrida da ascensão burguesa" (20), interpretação que vai desembocar na conhecida tese sobre o movimento de 30 , segundo a qual este movimento teria levado à revolução burguesa em nosso país. Este autor é bastante taxativo:

"A essência do movimento tenentista consistiu no seu papel ligado ao processo de ascensão da burguesia brasileira, em luta contra $o$ abso. luto domínio exercido pela classe latifundiária." (21)

Quanto a Edgar Carone e Leôncio Basbaum, para citar apenas dois autores muito conhecidos, sua visão do tenentismo também está inserida nos marcos desta primeira corrente. (22) Da mesma forma, Abguar Bastos, em seu já clássico Prestes e a Revolução Social, considera as revoluções de 1924 e 1930 como tipicamente pequeno-burguesas. (23) Como é assinalado por Maria Cecília Spina Forjaz, podem ainda ser identificados com esta corrente autores como Hélio Jaguaribe, Guerreiro Ramos e Wanderley Guilherme. (24)

Certamente, esta visão, em que se privilegia a origem social pequenoburguesa dos "tenentes" como fator definidor do caráter do movimento tenentista, encontra-se profundamente ligada à concepção "dualista" da sociedade brasileira, a qual por tantos anos imperou em nossa historiografia. Como é destacado com justeza por Boris Fausto, os elementos centrais desse modelo "dualista"

"podem ser assim resumidos: na formação social do país, existiria uma contradição básica entre o setor agrário exportador, representado pelo latifúndio semifeudal, associado ao imperialismo, e os interesses voltados

(19) - Santa Rosa, Virgínio. O Sentido do Tenentismo. Prefácio de Nélson Werneck Sodré, 3." ed. São Paulo, Alfa-Omega, 1976, p. 54.

(20) - Sodré, Nelson Werneck. A Coluna Prestes, obra citada, p. 32.

(21) - Sodré, Nélson Werneck. Prefácio a O Sentido do Tenentismo, de Virgínio Santa Rosa, obra citada, p. XVII.

(22) - Carone, Edgar. Obras citadas; Basbaum, Leôncio. História Sincera da República (de 1889 a 1930), 4.a ed. 2.0 Tomo. São Paulo, Alfa-Omega, 1981.

(23) - Bastos, Abguar, obra citada, p. 61.

(24) - Forjaz, Maria Cecília Spina. Tenentismo e Política. Tenentismo e Camadas Médias Urbanas na Crise da Primeira República. Rio de Janeiro, Paz e Terra, 1977, pp. 23-24. 
para o mercado interno, representados pela "burguesia". As disputas da Primeira República explicar-se-iam, em última análise, por esta oposição. assumindo as classes médias, identificadas com os movimentos militares, o papel de vanguarda das reivindicações burguesas." (25)

A partir do final dos anos 60 início dos anos 70, é possível identificar uma segunda corrente interpretativa do Tenentismo, representada principalmente por autores como Paula Beiguelman, Maria do Carmo Campello de Souza, Décio Azevedo Marques de Saes e Boris Fausto. (26) Sem dúvida, esta nova tendência historiográfica surgiu, em grande medida, como uma tentativa de contestar a absolutização da origem social na definição do conteúdo do Tenentismo, uma vez que esta interpretação vinha se tornando cada vez mais insuficiente na explicação dos fenômenos observados. Assim, Paula Beiguelman, em conhecido artigo, dedicado à crítica das posições "dualistas" de Nélson Werneck Sodré, ao contrapor-se à tese do Tenentismo como expressão dos anseios da classe média urbana, é levada a privilegiar um outro aspecto: os "tenentes" como parte de uma instituição do Estado. Afirma a autora:

"Podemos considerar que é principalmente ènquanto órgão responsável pela manutenção da ordem institucional que o grupo militar é sensibilizado pela crise política, tornando-se seja o principal fator da transformação revolucionária, seja o agente da consolidação do regime." (27)

Esta é também, em linhas gerais, a posição assumida por Maria do Carmo Campello de Souza. (28)

$\mathrm{O}$ professor Décio Azevedo Marques de Saes, em seu trabalho $\mathrm{O} \mathrm{Ci}$ vilismo das Camadas Médias Urbanas na Primeira República Brasileira (1889-1930), afirma que tentará explicar "o comportamento político do grupo militar na Primeira República (...) simultaneamente pela sua situação profissional como pela sua filiação às camadas médias urbanas". (29) Assim, diz:

(25) - Fausto, Boris. A Revolução de 1930. Historiografia e História. São Paulo, Brasiliense, 1970, p. 9.

(26) - Beiguelman, Paula. "A propósito de uma interpretação da História da República", in Pequenos Estudos em Ciência Política, 2." ed. ampliada. São Paulo, Pioneira, 1973; Campello de Souza, Maria do Carmo. "O processo político-partidário na Primeira República", in Brasil em Perspectiva, vários autores, 4. ${ }^{2}$ ed. São Paulo, Difusão Européia do Livro, 1973; Saes, Décio Azevedo Marques de. O Civilismo das Camadas Médias Urbanas na Primeira República Brasileira (1889-1930). (Cadernos do Instituto de Filosofia e Ciências Humanas da Universidade de Campinas, n. ${ }^{\circ}$ 1), 1973; Fausto, Bóris. A Revolução de 1930. Historiografia e História. São Paulo, Brasiliense, 1970; Pequenos Ensaios de História da República: 1889-1945. São Paulo, CEBRAP, 1972; "Expansão do café e política cafeeira", in História Geral da Civilização Brasileira. (III. O Brasil Republicano. 1. Estrutura de Poder e Economia (1889-1930). São Paulo, Difel, 1975.

(27) - Beiguelman, Paula, obra citada, p. 92.

(28) - Campello de Souza, Maria do Carmo, obra citada, p. 225.

(29) - Saes, Décio Azevedo Marques de, obra citada, p. 80. 
“A situação especificamente profissional do grupo militar determinou a forma dos movimentos políticos por eles liderados, enquanto as suas condições de integrante das camadas médias urbanas (e, como tal, preso ideologicamente às oligarquias) estabelecem os limites do seu conteúdo." (30)

Entretanto, no trabalho citado, o autor acaba por ser levado a uma interpretação em que se absolutiza um outro aspecto: a subordinação tanto das camadas médias urbanas, como dos militares às oligarquias dominantes na Primeira República. Consequientemente, o Tenentismo não teria um sentido anti-oligárquico, já que os militares "combatem com armas ideológicas subtraídas do próprio arsenal oligárquico". (31) Em última instância, os "tenentes" não representariam os interesses das camadas médias urbanas; sua ação resultaria principalmente de sua condição militar, condição esta que os impediria de assumir uma postura antioligárquica. Ássim, esta interpretação não deixa de ser uma outra forma de absolutizar o aspecto profissional, militar, na análise dos movimentos tenentistas.

E nos escritos de Boris Fausto, onde, talvez, fique mais explicitada a interpretação do Tenentismo representada por esta segunda corrente. Para este autor, carece de qualquer sentido identificar os "tenentes" com as chamadas camadas médias urbanas. (32) Afirma que "a análise do tenentismo não pode ser reduzida a explicações unilaterais, reduzindo o grupo funcional a uma classe social (tenentes e classe média), ou atribuindo ao grupo total autonomia no conjunto da sociedade." (33)

Entretanto, na prática, Boris Fausto é levado a absolutizar o aspecto militar do movimento tenentista, destacando ser este "um movimento política e ideologicamente difuso, de características predominantemente militares, onde as tendências deformistas autoritárias aparecem em embrião." (34) Para o autor, as tendências elitistas e autoritárias existentes entre os "tenentes" invalidam qualquer identificação sua com as camadas médias urbanas, cuja ideologia seria a liberal. $\mathrm{E}$ acrescenta: "Na base da pequena vinculação com os meios civis está um dos traços essenciais da ideologia tenentista: os 'tenentes' se identificam como responsáveis pela salvação nacional, guardiães da pureza das instituições republicanas, em nome do povo inerme. Trata-se de um movimento substitutivo e não organizador do povo." (35)

(30) - Id., ibid., p. 81.

(31) - Id., ibid., pp. 94-95. p. 62 .

(32) - Fausto, Boris. A Revolução de 1930. Historiografia e História, obra citada,

(33) - Fausto, Boris. Pequenos Ensaios de História da República : 1889-1945, obra citada, p. 30. p. 57.

(34) - Fausto, Boris. A Revolução de 1930. Historiografia e História, obra citada,

(35) - Id., ibid., pp. 57/58. 
A crítica a estas duas principais correntes historiográficas, em que, na interpretação do Tenentismo, são absolutizados, no primeiro caso, a origem social e as ligações dos "tenentes" com as camadas médias urbanas e, no segundo caso, o seu papel no aparelho de Estado enquanto fenômeno das Forças Armadas, levou, mais recentemente, ao surgimento de uma terceira corrente, a noso ver, mais próxima de uma análise global e não absolutizadora deste importante momento da História do Brasil. São representativos desta corrente autores como Paulo Sérgio Pinheiro, Maria Cecília Spina Forjaz e Anna Maria Martinez Corrêa. (36)

Assim, Paulo Sérgio Pinheiro, em seu livro Política e Trabalho no Brasil, destaca que a análise do papel dos "tenentes" deve ser feita através de duas dimensões: a primeira - "a situação atual ou recente, na época considerada, dos tenentes no aparelho militar do Estado", e a segunda "a relação entre os tenentes e as classes médias". E assinala ainda que "a conjugação dessas duas dimensões pode nos levar a uma explicação do fenômeno tenentista". (37)

Anna Maria Martinez Corrêa, ao estudar a rebelião de 1924 em São Paulo, considera que o papel dos "tenentes" deve ser analisado tanto no que se refere à sua procedência social (camadas médias), como à sua organização militar, incluindo o fato de ocuparem uma posição intermediária na hierarquia das Forças Armadas. (38)

Quanto a Maria Cecília Spina Forjaz, sua posição é de crítica às duas correntes historiográficas já examinadas. (39) Para a autora, ambas as correntes têm caráter absolutizador. Propôe que, na análise do Tenentismo, sejam levadas em conta tanto "sua situação institucional.. (dos tenentes) ... como membros do aparelho militar do Estado", como "sua composição social como membros das camadas médias urbanas". (40) E acrescenta:

(36) - Pinheiro, Paulo Sérgio. Política e Trabalho no Brasil (dos Anos Vinte a 1930). Rio de Janeiro, Paz e Terra, 1975; "Classes médias urbanas: formação, natureza, intervenção na vida política”, in História Geral da Civilização Brasileira. (III. O Brasil Republicano. 2. Sociedade e Instituições (1889-1930.) São Paulo, Difel, 1977; Forjaz, Maria Cecília Spina. Tenentismo e Política. Tenentismo e Camadas Médias Urbanas na Crise da Primeira República. Rio de Janeiro, Paz e Terra, 1977; Tenentismo e Aliança Liberal (1927-1930). São Paulo, Polis, 1978; Corrêa, Anna Maria Martinez. A Rebelião de 1924 em São Paulo. São Paulo, Hucitec, 1976.

(37) - Pinheiro, Paulo Sérgio. Política e Trabalho no Brasil (dos Anos Vinte a 1930), obra citada, p. 53.

(38) - Corrêa, Anna Maria Martinez, obra citada, p. 20.

(39) - Forjaz, Maria Cecília Spina. Tenentismo e Politica. Tenentismo e Cama. das Médias Urbanas na Crise da Primeira República, obra citada, pp. 23-27.

(40) - Id., ibid., p. 28. 


\begin{abstract}
“ $\mathrm{Na}$ conjuntura da década de vinte o tenentismo assumiu o papel de porta-voz das aspirações das camadas médias urbanas. Esse grupo social, por sua dependência estrutural das oligarquias dominantes, foi incapaz de organizar um partido político que expressasse seus interesses e que efetivamente contestasse a dominação oligárquica. Esse papel foi preenchido por um setor da burocracia estatal, os militares, que embora integrantes das camadas médias urbanas, possuem uma autonomia própria advinda de suas funçôes no aparelho de Estado.” (41)
\end{abstract}

A seguir, a autora, partindo desta nova visão da problemática do Tenentismo, chega a algumas conclusões interessantes a respeito da ambigüidade deste fenômeno:
“o tenentismo é liberal-democrata, mas manifesta tendências autoritá- rias; busca o apoio popular, mas é incapaz de organizar o povo; pre- tende ampliar a representatividade do Estado, mas mantém uma perspec- tiva elitista; representa os interesses imediatos das camadas médias urbanas, mas se vê como representante dos interesses gerais da naciona- lidade brasileira." (42)

Indiscutivelmente, a análise de Maria Cecília Spina Forjaz sobre o Tenentismo parece ser, por enquanto, a que mais se aproxima de uma interpretação não absolutizadora e, ao mesmo tempo, abrangente do fenômeno social e político, assim como ideológico, de complexidade tão grande. Somente a continuidade de nossos estudos poderá levar, talvez, a conclusões diferentes ou, pelo menos, que venham a incluir novos aspectos, ainda não percebidos.

Ainda no que se refere às análises existentes sobre o Tenentismo, a nosso ver, há uma grande falha a assinalar: o subjetivismo presente em parte considerável da historiografia referente a esse tema. É comum chegarse a conclusões generalizantes sem, para isto, ter-se estudado exaustivamente a realidade em questão, em toda a riqueza de sua diversidade. Se isto é verdade para os movimentos de 22 e 24 , muito mais o é para a Coluna Prestes, muito pouco pesquisada, como já tivemos oportunidade de destacar. São comuns, por exemplo, interpretações segundo as quais a Coluna teria realizado a sua Marcha "na tentativa de conscientizar o povo, principalmente o sertanejo, da necessidade de uma mudança no sistema político vigente", como escreve Lúcia de Fátima Guerra Ferreira (43), ou que "o objetivo político fundamental" da Coluna seria "fazer a propaganda arma-

(41) - Id., ibid., p. 31.

(42) - Id., ibid., pp. 31-32.

(43) - Ferreira, Lúcia de Fátima Guerra. A Coluna Prestes e a Paraíba. João Pessoa, Ed. Universitária, 1980, p. 20. 
da da revolução", nas palavras de Maria Cecília Spina Forjaz (44), ou ainda que a Coluna teria percorrido o interior do Brasil "tentando sublevar os camponeses", como afirma Paulo Gilberto Fagundes Vizentini. (45) Afirmações desse tipo carecem de um embasamento nos fatos.

$\mathrm{Da}$ mesma forma, são freqüentes as posturas teleológicas em que, hoje, a posteriori, pretende-se atribuir aos revolucionários da década de vinte planos traçados e amplamente elaborados desde o início. Por vezes, deparamonos com análises em que os "tenentes" já teriam, desde os primórdios de seu movimento, previsto todos os lances e desdobramentos da luta, inclusive a própria Revolução de 30 . O estudo mais acurado desse universo pode revelar-nos algo diferente: a indefinição, o espontaneísmo e uma grande dose de improvisação como características marcantes do Tenentismo. $O$ depoimento de Luiz Carlos Prestes é revelador nesse sentido: a própria Coluna não surgiu como fruto de uma decisão, de um plano estratégico; resultou de uma circunstância histórica, de uma realidade concreta em que só havia duas alternativas: capitular (entregando-se ou emigrando), ou marchar pelo país, evitando combates com um inimigo muitas vezes superior numérica e militarmente, mas tentando atraí-lo para o interior do Brasil e contribuindo dessa maneira para uma possível eclosão de novos levantes nas grandes cidades. $\mathrm{O}$ próprio desenrolar dos acontecimentos ia definindo as atitudes e decisões que eram tomadas pelos líderes do movimento. $\mathrm{Na}$ verdade, os "tenentes", não tinham um projeto elaborado.

Estas considerações relacionam-se diretamente com o problema da ideologia do Tenentismo e das diferentes correntes em que estaria dividido. Como é sabido, a historiografia é ampla sobre este assunto e os autores que dele se ocuparam (e que em grande parte já foram por nós citados) fizeram um esforço importante para determinar os traços mais característicos do universo ideológico do Tenentismo. Entretanto, persiste a tendência às generalizações. $E$ isto é particularmente notável no que se refere à Coluna Prestes. Episódio menos conhecido, é incluído sem mediaçōes e diferenciações no conjunto do Tenentismo e nele diluído, sendo que as conclusões que se tornaram voz corrente para o Tenentismo em geral lhe são atribuídas, sem que, para isso, seja analisado o fenômeno específico - a Coluna Prestes - o qual, sem dúvida, está inserido no Tenentismo, mas não se resume às generalidades que freqüentemente the são imputadas. Falta, a nosso ver, uma análise pormenorizada desse acontecimento; o seu estudo ajudaria a melhor definir o Tenentismo em seus diferentes momentos e em sua ideologia.

(44) - Forjaz, Maria Cecília Spina. Tenentismo e Politica. .., obra citada, p. 108. (45) - Vizentini, Paulo Gilberto Fagundes. Os Liberais e a Crise da República Velha. Tudo é História, n. ${ }^{\circ}$ 67. São Paulo, Brasiliense, 1983, p. 27. pp. 31-32. 
Não nos parecem aceitáveis, por exemplo, as tentativas existentes na literatura de identificar tendências claras e definidas no seio do Tenentismo, como o fazem Boris Fausto e Edgar Carone. Para o primeiro destes autores, na década de vinte, era possível detectar duas tendências no interior do Tenentismo: a primeira seria representada por Prestes, Siqueira Campos e Miguel Costa e estaria identificada com a derrubada das oligarquias, apresentando um "programa vagamente popular-nacionalista"; a segunda teria uma posição mais conservadora e seria representada por Juarez Távora. (46) Já para Edgar Carone, a divisão seria outra: o Tenentismo político dos Juarez e o Tenentismo social dos Luiz Carlos Prestes. (47)

A própria indefinição do Tenentismo, à qual já nos referimos, impede semelhante esquematização. As concepções liberais dos "tenentes", com algumas influências autoritárias de Alberto Torres, Oliveira Vianna, etc. (problema que precisa ser melhor investigado) eram de tal forma difusas e imprecisas, que seria impossível, no nosso entender, qualquer tentativa de identificação de tendências no seu bojo. Além disso, o Tenentismo era algo em transformação: as concepções de 1922 se distinguiam bastante das de 1930. Mas, mesmo em 30 , os "tenentes" não têm um programa definido e claro e, muito menos, existem correntes em luta.

O que se dá em 1930 é um acontecimento ímpar, imprevisto e inesperado para a maioria dos "tenentes": o rompimento de Prestes e sua adesão ao comunismo. Na medida que Prestes apresenta um programa - o seu Manifesto de maio de 1930 —, os "tenentes" sentem a necessidade imperiosa de definir-se, de elaborar e apresentar à sociedade o seu programa, o seu projeto. É nesse momento, portanto, e não antes, que os "tenentes" tentam apresentar um projeto articulado para o Brasil. Contudo, suas próprias limitações, sua dependência das classes dominantes, levam a que, no fundamental, venham a aderir ao programa das oligarquias dissidentes consubstanciado na plataforma da Aliança Liberal. Como é sabido, tentativas posteriores de projetos independentes dos "tenentes" viriam a fracassar, como é o caso do "Clube 3 de Outubro". Quanto a Prestes, fica sozinho, e não se pode dizer que venha a constituir uma "ala esquerda" do tenentismo, como afirma Décio Azevedo Marques de Saes. (48) Posteriormente, ele irá aderir ao PCB.

$\mathrm{Na}$ historiografia disponível, este aspecto foi percebido com bastante clarividência por Paulo Sérgio Pinheiro. Em seu livro já citado, afirma este autor:

"O tenentismo talvez tire sua maior consistência da necessidade que tem de se afirmar em face das opções formuladas por Prestes. O rompi-

(46) - Fausto, Boris. Pequenos Ensaios de História da República..., obra citada,

(47) - Carone, Edgar. O Tenentismo..., obra citada, p. 10.

(48) - Saes, Décio Azevedo Marques de, obra citada, pp. 95-96. 
mento de Prestes com seus antigos companheiros contribui para consolidar a presença do movimento dos tenentes ao redor de líderes como Juarez Távora, que se oporão claramente às opções do chefe da Coluna, o que lhes permitirá chegar a exercer uma influência importante no aparelho estatal após a revolução de 1930." (49)

No que diz respeito à historiografia referente especificamente à chamada Revolução de 30, já tivemos oportunidade de nos reportar à tese tradicional de encarar esse momento da História do Brasil como a consecução da suposta revolução burguesa. Trata-se da visão "dualista" de toda uma corrente importante em nossa historiografia (Virgínio Santa Rosa, Nélson Werneck Sodré, Egar Carone, Leôncio Basbaum, Wanderley Guilherme, etc.), cuja interpretação dos acontecimentos de 1930 se resumiria, em última instância, na ascensão da burguesia industrial ao poder seja através de seus representantes diretos, seja por intermédio das camadas médias urbanas, estas representadas pelos "tenentes".

$\mathrm{Na}$ crítica ao "dualismo" tiveram importância considerável os trabalhos de uma série de autores, como Florestan Fernandes, Fernando Henrique Cardoso, Boris Fausto, Paulo Sérgio Pinheiro, Wilson Cano, Sérgio Silva, etc., muitos dos quais revelaram a preocupação de entender os caminhos efetivos da implantação do capitalismo no Brasil. Esses estudos, em particular a identificação da oligarquia do café em São Paulo com uma suposta burguesia cafeeira (Fernando Henrique Cardoso, Wilson Cano, Sérgio Silva, Boris Fausto, etc.) (50), seriam um ponto de partida importante para a rediscussão dos acontecimentos de 1930. Não se trataria mais de uma revolução burguesa, uma vez que a burguesia, particularmente a burguesia cafeeira, seria a detentora do poder desde a proclamação da República e a burguesia industrial não teria interesse em substituí-la, já que "dadas as características da formação social do País, na sua metrópole interna há uma complementariedade básica entre interesses agrários e industriais", como ressalta Boris Fausto. (51)

Para este autor, "o colapso político da burguesia do café", em 1930, e a "incapacidade das demais frações de classe" para assumir 0 poder em 18-19.

(49) - Pinheiro, Paulo Sérgio. Politica e Trabalho no Brasil..., obra citada, pp.

(50) - Cardoso, Fernando Henrique. Capitalismo e Escravidão no Brasil Meridional: o Negro na Sociedade Escravocrata do Rio Grande do Sul. 2." ed. Rio de Janeiro, Paz e Terra, 1977; "Dos governos militares a Prudente-Campos Sales", in História Geral da Civilização Brasileira. (III. O Brasil Republicano. 1. Estrutura de Poder e Economia (1889-1930).) São Paulo, Difel, 1975; Cano, Wilson. Raízes da Concentração Industrial en São Paulo. São Paulo, Difel, 1977; Silva, Sérgio. Expansão cafeeira e origens da indústria do Brasil. São Paulo, Alfa-Omega, 1976; Fausto, Boris, obras citadas.

(51) - Fausto, Boris, A Revolução de $1930 \ldots$... obra citada, p. 112. 
caráter exclusivo teriam levado à única resposta possível: a formação do que ele chama de Estado de compromisso. Continuando sua análise, Boris Fausto diz que "o novo governo representa mais uma transação no interior das classes dominantes, tão bem expressa na intocabilidade sagrada das relações sociais no campo". (52) Quanto às forças que estariam envolvidas nesse Estado de compromisso, afirma o autor: "em equilíbrio instável, contando com o apoio das classes médias de todos os centros urbanos, reunemse o setor militar, agora ampliado com alguns quadros superiores, e as classes dominantes regionais". (53) Em outro momento, explicita-se melhor o problema, ao afirmar-se que "o acordo se dá entre as várias frações da burguesia" e "as classes médias - ou pelo menos parte delas - assumem maior peso, favorecidas pelo crescimento do aparelho de Estado, mantendo entretanto ume posição subordinada". (54) Fica claro que as oligarquias são identificadas com a burguesia.

Certamente, não é este o lugar para discutir com maior profundidade as teses de Boris Fausto e de outros autores. E importante ressaltar, entretanto, que o surgimento dessas novas correntes historiográficas, unificadas pela crítica ao "dualismo" e à concepção de uma suposta revolução burguesa em 1930, abriu caminho para que se puedesse pensar em outras interpretações para os acontecimentos das décadas de vinte e trinta no Brasil. Nesse particular, parece-nos fundamental a contribuição de Florestan Fernandes, ao recolocar a problemática da revolução burguesa no Brasil, entendendo-a como um processo complexo e demorado de transição para o capitalismo. (55)

Ainda considerando a historiografia sobre a Revolução de 30, deve-se mencionar uma nova corrente interpretativa representada por autores que trabalham na Universidade de Campinas (UNICAMP), como Edgar de Decca e Italo Tronca (56), para os quais o proletariado e o movimento popular teriam tido uma participação importante no movimento de 30 . Entretanto, esses autores não chegam a apresentar elementos convincentes para comprovar suas teses, que, na realidade, entram em conflito flagrante com tudo que se conhece a respeito da real correlação de forças sociais no final dos anos vinte no Brasil e, particularmente, da participação limitada da classe operária no movimento de 30 . A visão dos acontecimentos de 30 como um suposto golpe preventivo da burguesia contra o movimento operá-

(52) - Id., ibid., p. 113.

(53) - Id., ibid., p. 113.

(54) - Id., ibid., p. 104.

(55) - Fernandes, Florestan. A Revolução Burguesa no Brasil. Ensaio de Interpretação Sociológica. Rio de Janeiro, Zahar, 1975.

(56) - Decca, Edgar Salvador de. O Silêncio dos Vencidos. Prefácio de Marilena de Souza Chauí. São Paulo, Brasiliense, 1981; Tronca, Italo. Revolução de 30 : a Dominação Oculta. (Tudo é História, n. ${ }^{\circ}$ 42). São Paulo, Brasiliense, 1982. 
rio, que constituiria uma séria ameaça à dominação burguesa, não se sustenta diante da evidência dos fatos. Os autores de Campinas têm o objetivo de criticar a estratégia do PCB e sua política nos anos vinte, mas o subjetivismo a que são levados nas suas interpretações termina por invalidar seus intentos críticos.

Ao tentar fazer um balanço, mesmo que sumário, da historiografia consultada, concluímos, no que tange às análises do Tenentismo e do movimento de 30 , que essa produção historiográfica, no momento atual, ainda se ressente de uma deficiência fundamental: esses fenômenos continuam a ser interpretados segundo concepções teóricas evidentemente superadas e que não dão conta das transformações ocorridas no país. $\mathrm{Na}$ verdade, o Tenentismo e seus desdobramentos surgiram e se desenvolveram numa sociedade em crise - a República Velha na década de vinte -, o que torna necessário, para o seu entendimento, estudá-los à luz do que há de mais avançado no campo da teoria sócio-econômica. A teoria do escravismo colonial e sua passagem ao capitalismo nas condições brasileiras é, a nosso ver, o marco teórico adequado a essa análise.

Nesse sentido, Jacob Gorender, em sua obra fundamental $O$ Escravismo Colonial (57), e Ciro Flamarion Cardoso, em diversos escritos (58), assim como José de Souza Martins, em O Cativeiro da Terra (59), chegam a algumas conclusões importantes: com o fim do escravismo, a fazenda de café em São Paulo se teria transformado de imediato em fazenda capitalista, ou seja, não se dera a passagem automática da oligarquia escravista para uma suposta burguesia do café. Pelo contrário, o colonato não se constituiu numa relação de produção puramente assalariada, ou seja, capitalista. Durante algum tempo, na fazenda de café, as relações dominantes ainda não seriam propriamente capitalistas, encontrar-se-iam apenas num processo de transição para o capitalismo.

Não seria correto considerar que durante a República Velha o poder esteve fundamentalmente nas mãos dessa suposta burguesia do café. O que havia era algo mais complexo: uma oligarquia do café (em processo de aburguesamento, mas ainda não capitalista no que tange às relações de produção em que estava inserida) dominando o poder estatal desde os primei1978.

(57) Gorender, Jacob. O Escravismo Colonial. (Ensaios, 29). São Paulo, Ática,

(58) Cardoso, Ciro Flamarion S. Agricultura, Escravidão e Capitalismo. Petrópolis, Vozes, 1979; "El modo de producción esclavista colonial en América", in C. S. Assadourian et alii, Modos de Producción en América Latina. (Cuadernos de Pasado y Presente, n. 40). Buenos Aires, Siglo XXI, 1973; Cardoso, Ciro Flamarion S. e Brignoli, Héctor Perez. História Econômica da América Latina. Rio de Janiero, Graal, 1983.

(59) Martins, José de Souza. O Cativeiro da Terra. 2." Ed. São Paulo, Lech Livr. Ed. Ciências Humanas, 1981. 
ros anos da República, juntamente com outros setores oligárquicos e novos setores burgueses que se iam formando, inclusive na indústria. É importante destacar, contudo, que esses setores burgueses provinham em grande medida das próprias oligarquias tradicionais, o que determinava que seus interesses estivessem profundamente entrelaçados, apesar das contradições que se faziam presentes. Assim, Boris Fausto tem razão quando assinala que a burguesia industrial não pretendia substituir a suposta burguesia do café no poder.

Quanto à crise política dos anos vinte, entendemos que se tratava da crise desse sistema de dominação implantado com a República, em que a chamada dominação oligárquica significava o poder nas mãos da oligarquia do café e dos setores oligárquicos e industriais a ela aliados por uma série de interesses comuns. Nesse sentido, os trabalhos recentes de Winston Fritsch (60) são reveladores, ao mostrar que o Estado brasileiro não era um mero instrumento nas mãos dos cafeicultores, mas agia, em geral, em função dos interesses globais das classes dominantes. E, no seio destas, a burguesia industrial tinha um peso determinado e sua importância tendia a crescer. Os elementos apresentados nesses trabalhos, asim como no artigo inédito de Flávio Rabelo Versiani (61), mostram como, em contraposição a opinião amplamente divulgadas na literatura, a indústria cresceu e diversificou-se na década de vinte, em nosso país.

Dentro dessa perspectiva, as transformações que tiveram lugar como resultado do movimento de 30 consistiram num remanejamento de setores oligárquicos e burgueses no aparelho de Estado. Os setores ligados à oligarquia de São Paulo foram substituídos por outros, ligados às oligarquias gaúcha e mineira. Sem dúvida, essas mudanças ainda estão por ser estudadas com o devido cuidado. Parece-nos evidente, contudo, que os acontecimentos de 1930 devem ser comprendidos dentro dessa visão de um processo longo, difícil e tortuoso de transição do escravismo colonial para o capitalismo, em que, ao mesmo tempo em que as oligarquias tradicionais, principalmente a do café, iam sofrendo um processo de aburguesamento, novos setores burgueses vinham surgindo e se desenvolvendo, inclusive a burguesia industrial. Em 30, a crise do sistema de dominação implantado com a República, o esgotamento das possibilidades desse sistema atender aos interesses de setores oligárquicos e industriais que não participavam do poder, assim como as graves repercussões da crise capitalista mundial deflagrada em 1929, colocarem na ordem-do-dia o remanejamento no aparelho de Es-

(60) - Fritsch, Winston. Aspects of Brazilian Economic Policy under the First Republic (1889-1930). Tese de Doutoramento, Darwin College, Cambridge, 1983, mimeografado; "1924", in Pesquisa e Planejamento Econômico. Rio de Janeiro, IPEA, Vol. 10, dez./1980, n. ${ }^{\circ}$ 3, p. 713-774.

(61) - Versiani, Flávio Rabelo. "Industrialização: a década dos vinte e a depressão", 1983, mimeografado. 
tado com a conseqüente substituição de setores das classes dominantes no poder.

Em vez de uma revolução burguesa ou da formação de um Estado de compromisso, houve a substituição de um grupo oligárquico (e de seus setores aliados) por outros grupos oligárquicos (e seus setores aliados), sendo importante destacar que a burguesia industrial estava presente tanto na primeira, como na segunda composição de forças. Certamente, esse próprio remanejamento, aliado às condições internacionais e nacionais da época, determinaram que o novo Estado viesse a favorecer o processo de industrialização, que, entrementes, já vinha se dando no Brasil. É indiscutível que o desenvolvimento capitalista no país recebe um novo impulso a partir de 1930 e, para isso, contribuiram, em grande medida, as mudanças introduzidas pelo remanejamento havido no aparelho de Estado, a que fizemos referência. Os acontecimentos de 1930 representaram um momento importante, uma inflexão, no processo de passagem à formação sócio-econômica capitalista. Jamais uma revolução.

No que e refere às chamadas camadas médias e, em particular, aos "tenentes", o processo de industrialização e urbanização havia determinado - seu crescimento e conseqüente aspiração a uma maior participação na vida nacional, não obstante a sua grande dependência das classes dominantes. Desempenham um papel importante no movimento de 30 , mas sua participação no poder é limitada e passageira, sendo que os "tenentes" vão ser "usados" pelo novo poder, à frente do qual está um típico representante das oligarquias - Getúlio Dornelles Vargas.

\section{O depoimento de Luiz Carlos Prestes}

Com o propósito de estudar a Coluna Prestes, gravamos o depoimento de Luiz Carlos Prestes sobre o assunto. Trata-se de material que demanda uma análise cuidadosa e um meticuloso estudo comparativo com as outras fontes primárias e secundárias existentes e disponíveis. Contudo, desde já, é possível destacar algumas das contribuições mais importantes nele contidas.

Assim, mostram-se de grande interesse, para a compreensão do tema estudado, as opiniōes do comandante-em-chefe da Coluna sobre o Exército nos anos vinte e seu funcionamento interno, sobre a Escola Militar do Realengo, a oficialidade da época e a atuação da Missão Francesa, sobre os "tenentes" em particular e diversas personalidades da vida política daquele tempo, assim como os seus companheiros da Coluna.

Da mesma forma, constituem grande interesse os esclarecimentos referentes às causas que levaram ao surgimento dos movimentos tenentistas e, em particular, da Coluna Prestes. Como já assinalamos, fica evidente que os 
"tenentes" não tinham uma estratégia elaborada, nem planos bem delineados para seus movimentos. Era grande a dose de indefinição, espontaneismo e improvisação.

No que se refere mais especificamente à Coluna, o início da sua célebre Marcha foi algo que resultou das contingências históricas concretas: diante do avanço de um inimigo que contava com enorme vantagem numérica e de poder de fogo, não havia alternativa senão marchar pelo país, tentando evitar esse inimigo, distrair a sua atenção e atraí-lo para o interior, com o intuito de favorecer possiveis levantes militares nas principais cidades. Era a famosa "guerra de movimento", preconizada por Prestes em sua carta ao general Isidoro Dias Lopes, escrita de Barracão. (62) A outra opção seria emigrar para o estrangeiro, abandonando, portanto, a luta. Prestes mostra como esta foi a escolha de muitos que, uma vez engajados no levante, perceberam que a vitória não seria rápida, nem fácil, nem certa, como pensavam.

Diferentemente do que com freqüncia se imagina, a Coluna não foi uma campanha militar prevista com antecedência, com planos previamente traçados e objetivos claramente delineados. Pelo contrário, as soluções muitas de grande originalidade, como o rompimento do "anel de ferro" em São Luís, a ruptura do "fundo de garrafa" em que o general Rondon dizia ter encurralado os revolucionários, ou a famosa manobra do "laço húngaro" no norte de Minas Gerais - eram encontradas diante do próprio desenrolar dos acontecimentos, tendo como objetivo apenas sobreviver, continuar a luta, manter acesa a chama revolucionária, contribuir para que os "tenentes" que haviam ficado nas cidades organizassem novos levantes para derrubar o oligarca-mor, Artur Bernardes.

De maneira alguma, tinha a Coluna o objetivo de mobilizar as massas rurais, os camponeses, para a revolução. Os comandantes da Coluna não só não tinham uma estratégia traçada, como não sabiam bem o que pretendiam com a revolução em que falavam. Seu objetivo principial era a derrubada do presidente Bernardes. $O$ resto viria depois. $O$ voto secreto e algumas outras reivindicações que levantavam eram apresentados de forma vaga, imprecisa e sem jamais questionar o sistema dominante. Além disso, a ideologia dos jovens comandantes era claramente elitista: em nenhum momento se cogitou de mobilizar ou organizar as massas, muito menos as massas rurais, que eram consideradas completamente incapazes de qualquer participação efetiva na luta pelas transformações por que se batiam os "terentes". A concepção de Prestes e seus companheiros era a do golpe militar, da luta feita pelas forças militares. Durante a Marcha, a Coluna pretendia conseguir adesões e algumas foram alcançadas, principalmente no Mara-

(62) - Ver Moreira Lima, Lourenço, obra citada, p. 107-111. 
nhão e Piauí, mas tratava-se de adesões de soldados a um exército - a Coluna Prestes - , que dispunha de um comando militar e funcionava segundo as regras da disciplina militar, não obstante todo o espírito de solidariedade e companheirismo entre soldados e oficiais existente em suas fileiras. Não se tratava, portanto, da preparação de uma insurreição popular ou de uma guerra camponesa. No máximo, é possível identificar na Coluna algumas características de um exército popular; contudo, seu comando era estritamente militar, dele só participando os oficiais, ainda que estes tivessem conquistado o respeito e a obediência incondicional dos soldados pela sua abnegação, desprendimento e competência indiscutíveis na condução da luta.

No que se refere ao comportamento das populações rurais diante da Coluna, as informações contidas no depoimento de Prestes também são de grande valor. Para o homem do interior, o Governo significava serviço militar obrigatório, impostos escorchantes e repressão policial; na medida que a Coluna combatia o Governo, era vista com simpatia, mas o próprio fato de os revolucionários não terem nenhuma proposta concreta, nenhuma solução para essas populações terrivelmente espoliadas, não permitia que estas fossem sensibilizadas para uma participação efetiva na luta. Além disso, como já foi sublinhado, os revolucionários não pretendiam que essa participação se desse, não agiam com esse propósito. Buscavam apenas soldados para seu exército. Há que considerar ainda a sistemática propaganda governamental contra a Coluna (que era apresentada como um bando de bandidos e perseguida implacavelmente), o empenho de muitos "coronéis" do interior (que mobilizavam seus capangas contra a Coluna) e o vandalismo das tropas legalistas (que junto com os capangas dos "coronéis" iam cometendo toda sorte de desatinos por onde passavam, em perseguição aos revolucionários), como fatores importantes que explicam o medo e a atitude passiva ou até mesmo hostil de parte considerável das populações do interior diante da Coluna.

Um aspecto significativo que é lembrado por Prestes: a Coluna, por onde passava, não distinguia os fazendeiros dos camponeses, os homens ricos dos pobres do campo. Frequientemente, suas simpatias estavam com os fazendeiros. Para os comandantes revolucionários, o povo analfabeto, atrasado, ignorante, servia de massa de manobra aos donos do poder e dessa massa muito pouco se poderia esperar para a Revolução. Era uma visão tipicamente elitista, da qual decorria a despreocupação total pela propaganda junto às massas, por qualquer atividade de esclarecimento ou mobilização do povo do interior ou mesmo das cidades por onde a Coluna tinha a oportunidade de passar.

O depoimento de Prestes fornece uma riqueza muito grande de elementos concretos e desconhecidos sobre o levante no Rio Grande do Sul, 
em particular sobre uma série de combates, como o de Tupaceretã, e principalmente os detalhes do famoso cerco de São Luís e do seu rompimento por Luiz Carlos Prestes, dando início à Marcha da Coluna propriamente dita. São acontecimentos que, mesmo no livro citado de S. Dias Ferreira (63) - aquele que melhor retrata a campanha do Rio Grande do Sul -, estão apresentados de forma incompleta e deturpada, o que em grande parte se explica pelo fato de seus autores não serem militares, nem estarem a par dos detalhes do plano estratégico de Prestes, o qual era de conhecimento de apenas uns poucos oficiais mais chegados a ele. A partir dos elementos fornecidos por Prestes, é possível traçar o mapa da real disposição das tropas da Coluna em torno de São Luís e de seu posterior e rápido deslocamento para São Miguel, de onde partiram, já unidas, em direção ao norte.

Durante o desenrolar dos acontecimentos ocorridos ainda no Rio Grande do Sul, é interessante verificar como a Coluna, que no início era bastante desorganizada, faltando-lhe unidade de comando, aos poucos vai sendo organizada e adquirindo, sob a direção de Prestes, um comando unitário, competente e eficaz, condição fundamental para sua sobrevivência ao longo de aproximadamente 25 mil quilômetros, durante os quais nunca sofreu nenhuma derrota.

Quando chega ao Paraná, a Coluna dirigida por Prestes já é um exército organizado, com alto espírito de combatividade e ânimo elevado por ter vencido tantas dificuldades e conseguido encontrar-se com os revolucionários de São Paulo, há vários meses imobilizados nas barracas do $\mathrm{Pa}$ raná. São de inestimável valor as observações de Prestes sobre as defecções que a Coluna veio sofrendo até chegar ao Paraná, sobre o comportamento de muitos daqueles oficiais que se haviam levantado no Rio Grande do Sul, sobre a participação do caudilho de Santa Catarina, Fidêncio de Melo, sobre a luta travada por Prestes para conseguir transformar os revoltosos de outubro de 1924 no Rio Grande do Sul naquilo que viria a ser um exército organizado e disciplinado - a Coluna Prestes.

Outro aspecto a destacar nas entrevistas de Prestes são suas apreciações sobre a tática do general Isidoro e do comando da Coluna de São Paulo, que se manteve imobilizada durante mais de seis meses na região paranaense que se estende da serra do Medeiros ao rio Paraná. Particularmente interessante são as observações de Prestes sobre a rendição de Catanduvas, o comportamento do tenente Nelson de Melo, que comandava as tropas revolucionárias na frente de Catanduvas, o ataque do tenente $\mathrm{Ca}$ banas a Formigas e o comportamento deste último diante do plano de Prestes para tentar encurralar o general Rondon, comandante-em-chefe das

(63) - Ferreira, S. Dias, obra citada. 
tropas legalistas. Nesse sentido, é extremamente revelador comparar o que escreve João Cabanas em seu famoso livro A Coluna da Morte (64) e o que revela L. C. Prestes em seu depoimento.

Às concepções militares dos chefes legalistas Prestes faz observações de profundo conteúdo crítico, revelando como os ensinamentos da Missão Militar Francesa, baseados na "guerra de posição", levaram os generais brasileiros, numa visão extremamente dogmática, a aplicar uma tática que os conduziria a derrotas sucessivas - a tática de perseguir o objetivo geográfico -, determinando seu total fracasso diante da "guerra de movimento" posta em prática pela Coluna. As derrotas legalistas em São Luís (no Rio Grande do Sul), no Paraná - ao tentar liquidar com a Coluna -, e mais tarde durante toda a Marcha servem de comprovação de que Prestes está com a razão. Aliás, como é assinalado por nosso entrevistado, o único oficial legalista que compreendeu que era necessário mudar de tática, desistir da perseguição à Coluna e tentar encontrar uma solução política foi o major Bertoldo Klinger, que, por isso, sofreu perseguições, esteve preso e chegou a ser julgado e condenado. Prestes considera que os capítulos do livro de Klinger, Parada e desfile de uma vida de voluntário do Brasil (65), em que narra os combates que travou contra a Coluna, correspondem ao que realmente se passou e suas opiniões revelam uma postura extremamente objetiva na avaliação das diferentes situações concretas.

Após a derrota de Catanduvas quando Prestes e sua Coluna chegam ao Paraná, tem lugar, em Foz do Iguaçu, uma importante reunião da oficialidade de ambas as colunas, a de São Paulo e a do Rio Grande do Sul, para decidir dos destinos da Revolução. É um episódio da maior importância que, entretanto, permanece desconhecido, uma vez que está ausente das páginas dos poucos livros existentes sobre o asunto. Prestes faz revelações extremamente esclarecedoras, mostrando como, entre cerca de 40 ofíciais presentes nessa reunião, a maioria só desejava uma coisa: emigrar, abandonando a luta. Era este o estado de espírito dominante; aqueles oficiais sentiam-se derrotados e sem perspectiva, pensando somente em ir embora. Prestes e sua Coluna vinham com outra perspectiva, queriam continuar a luta, não aceitavam a hipótese de abandonar tudo quando, após tantos esforços e sacrifícios, haviam conseguido chegar ao Paraná com uma tropa organizada e combativa, disposta a enfrentar todos os percalços que fossem necessários para dar continuidade à luta que vinham travando há seis meses. Enquanto Prestes falava, nesa reunião de Iguaçu, defendendo com entusiasmo o prosseguimento da Marcha - e para isso era necessário invadir o Paraguai, reingressando no Brasil por Mato Grosso -, grande

(64) - Cabanas, João. A Coluna da Morte sob o Comando do Tenente Cabanas. 4." ed. Rio de Janeiro, s/d.

(65) - Klinger, Bertoldo, obra citada. 
parte da oficialidade ia levantando-se e dirigindo-se para o Paraguai, abandonando o exército revolucionário, pois considerava que não havia mais nada a fazer. E interessante comparar estas informações com o que diz João Alberto Lins de Barros em suas memórias: nessa reunião teria sido tomada a decisão unânime de atravessar o Paraná em direção a Mato Groso... (66) A reconstituição histórica dessa reunião em Foz do Iguaçu - marco fundamental para a continuação da Marcha da Coluna - é um dos aspectos mais importantes de nossa pesquisa, para a qual o depoimento de Prestes revela-se de valor inestimável.

No que se refere à Marcha da Coluna após seu ingresso em Mato Grosso, Prestes, em suas entrevistas, fornece um rico material para o esclarecimento de muitos fatos e episódios, alguns registrados com imprecisões ou exageros pelos poucos relatos existentes desses acontecimento,s outros inteiramente desconhecidos. Assim, por exemplo, são extremamente interessantes e esclarecedoras as considerações que tece sobre suas divergências com o general Miguel Costa quando do combate em Cabeceira do Apa; já naquele momento, Prestes entendia que, na "guerra de movimento" que vinham travando, com recursos muito limitados e sem dispor de fábrica de munição, era necessário evitar "combates decisivos", que, numa visão diferente, ainda eram defendidos por Miguel Costa.

Mesmo no famoso combate de Zeca Lopes (em Goiás), essa concepção da necessidade de travar "combates decisivos" ainda era muito forte no comando da Coluna. Foi a própria experiência, com a perda de vidas preciosas e muito armamento, que determinou a vitória das idéias defendidas por Prestes, estabelecendo-se na Coluna o ponto de vista de que era necessário evitar, sempre que possível, confrontos com o inimigo. $O$ mais importante para a Coluna era sobreviver e prosseguir na marcha pelo interior do país, atraindo as tropas legalistas e facilitando, dessa forma, a preparação de novos levantes nas cidades. A partir do combate na fazenda Zeca Lopes, com as tropas de Bertoldo Klinger, a concepção da "guerra de movimento", proposta por Prestes, estava vitoriosa.

A reorganização da Coluna em Mato Grosso é outro momento importante, para o qual os esclarecimentos de Prestes são valiosos. Por exemplo, a atitude de Juarez Távora, resistindo até o final a essa reorganização que viria melhorar muito o desempenho das tropas revolucionárias, é algo desconhecido na literatura sobre o assunto. $\mathrm{O}$ próprio Juarez Távora, em suas obras, não faz nenhuma referência ao fato.

A passagem da Coluna pelos estados do Maranhão e Piauí é uma página fundamental em sua história. Prestes fornece muitas informações

(66) — Lins de Barros, João Alberto, p. 86. 
esclarecedoras, que vêm corrigir alguns aspectos da narrativa de Lourenço Moreira Lima. Em particular, são interessantes suas observações sobre os acontecimentos no rio Parnaíba e a tática empregada pelo comando revolucionário diante da fuga desabalada das tropas legalistas acantonadas nas cidades de Benedito Leite e Uruçuí.

Sobre os acontecimentos em Piancó (Paraíba), Prestes também apresenta dados importantes e, sem pretender encobrir o fato do justiçamento do padre Aristides e seus capangas (o que, de alguma forma, é feito no livro de S. Dias Ferreira) (67), esclarece as circunstâncias e os motivos que levaram os combatentes da Coluna a fazerem justiça pelas próprias mãos.

As difíceis condições que a Coluna enfrentou em Pernambuco e a retificação de uma série de fatos narrados com imprecisão e falhas por Lourenço Moreira Lima - é preciso considerar que o secretário da Coluna não era militar e freqüentemente não estava a par das manobras que eram traçadas e executadas pelo comando - , são um aspecto a destacar de Prestes.

$\mathrm{Da}$ mesma forma, uma série de outros fatos, acontecimentos e aspectos são abordados por Luiz Carlos Prestes em seu depoimento, os quais devidamente examinados e comparados com os demais elementos disponíveis podem constituir um acervo do maior valor para a reconstituição e avaliação da Coluna que tomou seu nome.

A forma como a Coluna partiu para o exílio também merece ser melhor estudada, e as entrevistas de Prestes ajudam a esclarecer como os revolucionários encerraram sua longa marcha de aproximadamente $25 \mathrm{mil}$ quilômetros. Não só fica confirmado o que dissera Lourenço Moreira Lima: "Não vencemos, mas não fomos vencidos." (68) Na verdade, a Coluna deixou o Brasil organizada e consciente de que havia cumprido o seu dever. Prestes recorda que, antes de atravessar a fronteira com a Bolívia, o comando da Coluna reuniu todos os seus soldados para explicar-lhes por que havia sido decidido emigrar: por um lado, o objetivo inicial de derrubar o presidente Bernardes perdera o sentido, na medida que já havia começado o quadriênio de Washington Luiz, trazendo consigo a esperança de uma possível anistia; por outro lado, principalmente para Prestes, já estava claro que a simples substituição de homens no poder nada resolveria. Era preciso buscar as causas sociais que determinavam a miséria em que vivia o povo brasileiro e que tanto impressionara a Prestes e alguns de seus companheiros. Para Prestes, que tinha o comando indiscutível da

(67) - Ferreira, S. Dias, obra citada.

(68) - Moreira Lima, Lourenço, obra citada, p. 500. 
Coluna, chegara a hora de encerrar a Marcha e procurar nos livros a explicação para a situação em que se encontravam o país e o seu povo. Dessa explicação deveria resultar a nova solução a ser aplicada.

Assim como a Coluna Prestes, para ser entendida, tem que ser analisada no quadro geral dos movimentos tenentistas da década de vinte, em sua ligação com os levantes de 1922 no Rio e 1924 em São Paulo, a chamada Revolução de 30 também não pode ser compreendida fora de suas conexões com a Coluna. Prestes esclarece um aspecto muito importante e que, em geral, não é destacado: enquanto a Coluna marchava pelo interior do país, nas grandes cidades do litoral praticamente não se falava nela; a censura era rígida, impedindo que a imprensa tocasse no assunto. E a partir do momento em que a Coluna vai para o exílio, em fevereiro de 1927, que ela se torna notícia. E isso também não é por acaso. Não só havia um clima de maior liberdade no Brasil, com a posse de Washington Luiz e a suspensão do estado de sítio e da censura à emprensa, como Luiz Carlos Prestes - o Cavaleiro da Esperança - e seus companheiros, ungidos com a auréola de heróis, despontavam para os políticos liberais da oposição como uma bandeira a ser aproveitada e utilizada em sua pugna pelo poder. A partir de então, o nome de Prestes e da Coluna passam a ser usados pelas oligarquias dissidentes e, na campanha da Aliança Liberal, falava-se em nome dos ideais revolucionários da Coluna Prestes e do Cavaleiro da Esperança. Este aspecto não pode deixar de ser considerado em todos seus desdobramentos quando se estuda o movimento de 30 e a chamada Revolução de 30 .

\section{Conclusão}

A Coluna Prestes, assim como o movimento tenentista de uma maneira geral, era reflexo, a nível da história social, das transformaçōes que vinham ocorrendo no Brasil durante a Primeira República e terminariam por levar à crise dos anos vinte. $O$ processo então em curso de transição, do escravismo colonial - que havia sido liquidado com a abolição - ao capitalismo, dentro de toda sua complexidade, exigia mudanças na vida política, de cuja necessidade os revolucionários da época foram expressão, apesar de não terem uma consciência clara do papel que desempenhavam.

Para tentar entender esses processos e chegar a escrever uma história da Coluna Prestes, a metodologia marxista é, a nosso ver, o único instrumental válido. Como é destacado por Pierre Vilar, é preciso chegar a uma "história da sociedade em movimento" (69), ou seja, a uma história sintese,

(69) - Vilar, Pierre. "La méthode historique", in Dialectique Marxiste et Pensée Structurale. Tables Rondes à Propos des Travaux d'Althusser. Cahiers du Centre d'Etudes Socialistes, Paris, 1968, p. 35-43. 
que, em última instância, deve integrar os resultados de todas as pesquisas efetuadas em todos os domínios, reunindo-as, como diz Georges Duby, "na unidade de uma visão global" (70).

Para atingir esse objetivo, não basta comparar as informações contidas no depoimento de Prestes com as existentes no maior número possível de fontes (este é apenas um aspecto de trabalho, ainda que fundamental); é indispensável atingir um conhecimento profundo e multifacético do Brasil na época em questão. Sem isto, qualquer pretensão de escrever uma "história da sociedade em movimento" estará fadada ao mais completo fracasso.

A História da Coluna Prestes não deverá ser nem um diário da Coluna, como a obra fundamental de Lourenço Moreira Lima (71), nem um relato valioso como o de S. Dias Ferreira (com a colaboração de Sady Valle Machado) (72), nem recordações esparsas como as de Juarez Távora (73) e João Alberto Lins de Barros (74), nem um depoimento rápido e superficial como o de Osvaldo Cordeiro de Farias (75), nem sequer um depoimento bastante completo como o de Luiz Carlos Prestes. Queremos escrever a História no sentido marxista, a História em que os fatos são interpretados $e$ inseridos na sua época e a época, por sua vez, tem um "antes" e um "depois".

(70) - Duby, Georges. "Les Sociétés Médiévales. Une Approche d'Ensemble", in Annales E.S.C., janeiro-fevereiro de 1971, p. 1-13.

(71) - Moreira Lima, Lourenço, obra citada.

(72) - Ferreira, S. Dias, obra citada.

(73) - Távora, Juarez, obras citadas.

(74) - Lins de Barros, João Alberto, obra citada.

(75) - Farias, Osvaldo Cordeiro de, obra citada. 


\section{BIBLIOGRAFIA CONSULTADA}

ALENCAR ARARIPE, Tristão de. Tasso Fragoso. Um Pouco de História do Nosso Exército. Rio de Janeiro, Ed. Biblioteca do Exército, 1960.

ANDRADE, Paulo René de. Três Revoluções. (A Atuação da Polícia Militar de Minas Gerais, a Antiga Força Pública, nos Movimentos Revolucionários de 1924, 1930 e 1932.) $10^{\circ}$ volume. Belo Horizonte, Imprensa Oficial, -976; $2 .^{\circ}$ volume. Belo Horizonte, Imprensa Oficial, 1978.

ARANHA, Graça. A Viagem Maravilhosa. Rio de Janeiro, Livr. Garnier, 1929.

AURELIANO, Liana Maria. No Limiar da Industrialização. São Paulo, Brasiliense, 1981.

BASBAUM, Leôncio. História Sincera da República. 4 volumes. 4." ed. São Paulo, Alfa-Omega, 1981.

BASTOS, Abguar. Prestes e a Revolução Social. (Fatos Politicos, Condições Sociais e Causas Econômicas de Uma Fase Revolucionária do Brasil). Rio de Janeiro, Ed. Calvino, 1946.

BEIGUelman, Paula. Pequenos Estudos em Ciência Politica. 2." ed. ampliada. São Paulo, Pioneira, 1973.

BELlo, José Maria. História da República (1889-1954): Sintese de Sessenta e Cinco Anos da Vida Brasileira. 7. ${ }^{a}$ ed. São Paulo, Comp. Ed. Nacional, 1976.

BEUREN, Jacó. O Tenente Portela na Marcha da Coluna Revolucionária. Porto Alegre, Gráfica Ed. A Nação S.A., 1969.

CABANAS, João. A Coluna da Morte sob o Comando do Tenente Cabanas. 4. ${ }^{*}$ ed. Rio de Janeiro, s/d.

CAMPELLO DE SOUZA, Maria do Carmo. "O processo político-partidário na Primeira República, in Brasil em Perspectiva, vários autores. $4 .^{\circ}$ ed. São Paulo, Difusão Européia do Livro, 1973.

CANO, Wilson. Raízes da Concentração Industrial em São Paulo. São Paulo, Difel, 1977.

CARDOSO, Ciro Flamarion S. Agricultura, Escravidão e Capitalismo. Petrópolis, Vozes, 1979.

- "El modo de producción esclavista colonial en América", in C. S. Assadourian et alii, Modos de Producción en América Latina. (Cuadernos de Pasado y Presente, n. ${ }^{\circ} 40$ ). Buenos Aires, Siglo XXI, 1973.

CARDOSO, Ciro Flamarion S. e BRIGNOLI, Héctor Perez. História Econômica da América Latina. Rio de Janeiro, Graal, 1983.

CARDOSO, Fernando Henrique. Capitalismo e Escravidão no Brasil Meridional: o Negro na Sociedade Escravocrata do Rio Grande do Sul. 2. ${ }^{\mathrm{a}}$ ed. Rio de Janeiro, Paz e Terra, 1977. 
- "Dos governos militares a Prudente-Campos Sales", in História Geral da Civilização Brasileira. (III. O Brasil Republicano. 1. Estrutura do Poder e Economia (1889-1930.) São Paulo, Difel, 1975.

CARNEIRO, Glauco. História das Revoluções Brasileiras. 2. volumes. Rio de Janeiro, O Cruzeiro, 1965.

- O Revolucionário Siqueira Campos, 2 volumes. Rio de Janeiro, Record, 1966.

- Lusardo, o Ultimo Caudilho. 2 volumes. $2 .^{a}$ ed. Rio de Janeiro, Nova Fronteira, 1977.

CARONE, Edgar. Revoluçōes do Brasil Contemporâneo. 2.a ed. São Paulo, Difel, 1975.

CARONE, Edgar. O Tenentismo (Acontecimentos - Personagens - Programas). São Paulo, Difel, 1975.

- A República Velha. I. Instituições e Classes Sociais. 4." ed. São Paulo, Difel, 1978.

- A República Velha. II. Evolução Política (1889-1930). 3.² ed. São Paulo, 1977.

CASTRO CARVALHO, Euclydes. Revolução de 1924. Rio Grande do Sul, Ed. E. Carvalho-Prata, 1924.

CASTRO, Sertório de. A República que a Revolução destruiu. 2.a ed. Brasília, Ed. Universidade de Brasília, 1982.

CHEVALIER, Carlos. Os 18 do Forte. Rio de Janeiro, 1930.

COELHO LISBOA, Rosalina. A Seara de Caim - Romance da Revolução Brasileira. 5. ${ }^{\mathrm{a}}$ ed. Rio de Janeiro, Livr. José Olympio Ed., 1956.

CORREA, Anna Maria Martinez. A Rebelião de 1924 em São Paulo. São Paulo, Hucitec, 1976.

COSTA, Cyro e GOES, Eurico de. Sob a Metralha... (História da Revolta em São Paulo, de 5 de julho de 1924). São Paulo, Cia. Gráphico-Ed. Monteiro Lobato, 1924.

COSTA FILHO, Miguel. Os Farsantes da Revolução. Rio de Janeiro, 1931.

DANTAS, Ibaré Costa. O Tenentismo em Sergipe. Petrópolis, Vozes, 1974.

- A Revolução de 1930 em Sergipe. (Dos Tenentes aos Coronéis.) São Paulo, Ed. Cortez Aracaju, Universidade Federal de Sergipe, 1983.

DECCA, Edgar Salvador de. O Silêncio dos Vencidos. Prefácio de Marilena de Souza Chauí. São Paulo, Brasiliense, 1981.

- O Nascimento das Fábricas. (Tudo é História, n.o 51). São Paulo, Brasiliense, 1982.

DULlES, John W. F. Anarquistas e Comunistas no Brasil, 1900-1935. Tradução de César Parreiras Horta. Rio de Janeiro, Nova Fronteira, 1977.

FARIAS, Osvaldo Cordeiro de. Meio Século de combate: Diálogo com Cordeiro de Farias. (Por Aspásia Camargo e Walder de Goes). Rio de Janeiro, Nova Fronteira, 1981. 
FAUSTO, Boris. A Revolução de 1930. Historiografia e História. São Paulo, Brasiliense, 1970.

- Pequenos Ensaios de História da República: 1889-1945. São Paulo, CEBRAP,

- "Expansão do café e política cafeeira", in História Geral da Civilização Brasileira. III. O Brasil Republicano. 1. Estrutura de Poder e Economia (1889. 1930). São Paulo, Difel, 1975.

FERNANDES, Florestan. A Revolução Burguesa no Brasil. Ensaio de Interpretação Sociologica. Rio de Janeiro, Zanar, 1975.

FERrEIRA, S. Dias (e Sady Valle Machado). A Marcha da Coluna Prestes. Pelotas, Livraria Globo, 1928.

FERreIRA, Lúcia de Fátima Guerra. A Coluna Prestes e a Paraíba. João Pessoa, Ed. Universitária, 1980.

FORJAZ, Maria Cecília Spina. Tenentismo e Politica. Tenentismo e Camadas Médias Urbanas na Crise da Primeira República. Rio de Janeiro, Paz e Terra, 1977. Tenentismo e Aliança Liberal (1927-1930). São Paulo, Polis, 1978.

FRANCO, Maria Sylvia de Carvalho. Homens Livres na Ordem Escravocrata. 2. ed. São Paulo, Atica, 1976. (Ensaios, 3).

FRANCO, Virgílio A. de Melo. Outubro, 1930. 5.` ed. Rio de Janiero, Nova Fronteira, 1980.

FRITSCH, Winston. Aspects of Brazilian Economic Policy under the First Republic (1889-1930). Tese de Doutoramento, Darwin College, Cambridge, 1983, mimeografado.

- “1924”, in Pesquisa e Planejamento Econômico. Rio de Janeiro, IPEA, vol. 10, dez./1980, n. 3, pg. 713-774.

FURTADO, Celso. Formação Econômica do Brasil. 8." ed. São Paulo, Ed. Nacional, 1968.

GORENDER, Jacob. O Escravismo Colonial. (Ensaios, 29). São Paulo, Ática, 1978. A Burguesia Brasileira. (Tudo é História, 29). São Paulo, Brasiliense, 1981.

GUSMÃO DE SAMPAIO TORRES, Rosa Maria. "Os ideais tenentistas e a estrutura de classes", artigo baseado em monografia de bacharelado no Departatamento de História da PUC/RJ, 1980, mimeografado, 19 páginas.

KLINGER, Bertoldo. Narrativas Autobiográficas. Vol. III - Tempo Quente de Major. Rio de Janeiro, E. O Cruzeiro, 1948; Vol. IV - 380 Léguas de Campanha em 3 Meses. Rio de Janeiro, Ed. o Cruzeiro, 1949.

- Parada e Desfile de Uma Vida de Voluntário do Brasil (na primeira metade do século). Rio de Janeiro, Empresa Gráfica 'O Cruzeiro”, 1958.

LACERDA, Maurício de. Segunda República. 2." ed. Rio de Janeiro, Livr. Ed. Freitas Bastos, 1931.

LANDUCCI, Italo. Cenas e Episódios da Revolução de 1924 e da Coluna Prestes. 2." ed. São Paulo, Brasiliense, 1952. 
LEAL, Aristides. Depoimento. 1975/7. Rio de Janeiro, FGV/CPDOC - História Oral, 1979. Cópia xerox do depoimento gravado e transcrito.

LINHARES, Maria Yedda Leite. "Vargas: a tomada do Poder", in Tempo Brasileiro, n. ${ }^{\circ}$ 8, Rio de Janeiro, Ed. Tempo Brasileiro, fevereiro/1966.

LINHARES, Maria Yedda Leite e TEIXEIRA DA SILVA, Francisco Carlos. História Política do Abastecimento (1918-1974). Brasília, BINAGRI, 1979.

LINS DE BARROS, João Alberto. Memórias de um Revolucionário. 1." parte: A Marcha da Coluna. Rio de Janeiro, Ed. Civ. Brasileira, 1953.

MACAULAY, Neill. A Coluna Prestes. São Paulo, Difel, 1977.

MALTA, Octávio. Os Tenentes na Revolução Brasileira. Rio de Janeiro, Civilização Brasileira, 1969.

MARTINS, José de Souza. O Cativeiro da Terra. 2." ed. São Paulo, LECH - Livr. Ed. Ciências Humanas, 1981.

MARTINS FILHO, Amilcar Vianna. A Economia Politica do Café com Leite: 19001930. Belo Horizonte, Universidade Federal de Minas Gerais, 1981.

MOREIRA LIMA, Lourenço. A Coluna Prestes (Marchas e Combates). 3." ed. facsimilada e ilustrada. São Paulo, Alfa-Omega, 1979.

NORONHA, Abílio. Narrando a Verdade. Contribuição para a História da Revolta em São Paulo. São Paulo, 1924.

- O Resto da Verdade. (Contribuição para a História da Revolta em São Paulo). São Paulo, Empresa Ed. Rochéa, 1925.

NUNES DE CARVALHO, Joaquim. A Revolução no Brasil (1924-1925) - Apontamentos para a História. 3., ed. Março de 1931.

- $O$ Terceiro 5 de Julho. Rio de Janeiro, 1952.

OLIVEIRA, Nelson Tabajara de. 1924 - a Revolução de Isidoro. São Paulo, Comp. Ed. Nacional, 1956.

OtAVIANO, Manuel. A Coluna Prestes na Paraíba (Os Mártires de Piancó). 2." ed. João Pessoa, Ed. Acauã, 1979.

PINHEIRO, Paulo Sérgio. Politica e Trabalho no Brasil (dos Anos Vinte a 1930). Rio de Janeiro, Paz e Terra, 1975.

-- "Classes médias urbanas: formação, natureza, intervenção na vida política", in História Geral da Civilização Brasileira. III. O Brasil Republicano. 2. Sociedade e Instituições (1889-1930). São Paulo, Difel, 1977.

REVERBEL, Carlos (org.). Diário de Cecília de Assis Brasil (período 1916-1928). Porto Alegre, L\&PM, 1983.

SAES, Décio Azevedo Marques de. O Civilismo das Camadas Médias Urbanas na Primeira República Brasileira (1889-1930). (Cadernos do Instituto de Filosofia e Ciências Humanas da Universidade Campinas, n. 1), 1973. 
SANTA ROSA, Virgínio. O Sentido do Tenentismo. Prefácio de Nelson Werneck Sodré. 3. ${ }^{a}$ ed. São Paulo, Alfa-Omega, 1976.

SILVA, Hélio. 1889 : A República Não Esperou o Amanhecer. Rio de Janeiro, Civ. Brasileira, 1972.

- 1922 : Sangue na Areia de Copacabana. (O ciclo de Vargas - Vol. 1). 2.a ed. Rio de Janeiro, Civ. Brasileira, 1971.

- 1926 : A Grande Marcha. (O ciclo de Vargas - Vol. II). 2. ed. Rio de Janeiro, Civ. Brasileira, 1971.

- 1930 : A Revolução Traída. (O ciclo de Vargas - Vol. III). Rio de Janeiro, Civ. Brasileira, 1966.

SILVA, Sérgio. Expansão Cafeeira e Origens da Indústria no Brasil. São Paulo, Alfa-Omega, 1976.

SODRE, Nelson Werneck. História Militar do Brasil. 2. ed. Rio de Janeiro, Civ. Brasileira, 1968.

- A Coluna Prestes. Análise e Depoimentos. Rio de Janeiro, Civ. Brasileira, 1978.

TAVORA, Juarez. A Guisa de Depoimento sobre a Revolução Brasileira de 1924. 1. volume. São Paulo, "O Combate", 1927; $3 .^{\circ}$ volume. Rio de Janeiro, Mendonça, Machado e C., 1928. (O 2. ${ }^{\circ}$ volume não foi publicado).

- Uma Vida e Muitas Lutas - Memórias. $1^{\circ}$ volume - Da Planície à Borda do Altiplano. Rio de Janeiro, Livr. José Olympio, 1973. 2..$^{\circ}$ volume $-A$ Caminhada no Altiplano. Rio de Janeiro, Livr. José Olympio, 1974. 3..$^{\circ}$ volume - Voltando à Planície. Rio de Janeiro, Biblioteca do Exército Ed., 1977.

TRONCA, Italo. Revolução de 30 : A Dominação Oculta. (Tudo é História, 42). São Paulo, Brasiliense, 1982.

VERSIANI, Flávio Rabelo e MENDONÇA DE BARROS, José Roberto (org.). Formação Econômica do Brasil (A Experiência da Industrialização). (Série ANPEC de leituras de economia). São Paulo, Saraiva, 1978.

VERSIANI, Flávio Rabelo. "Industrialização: a década dos vinte e a depressão", 1983, mimeografado.

VILleLA, Annibal Villanova e SUZIGAN, Wilson. Politica do Governo e Crescimento da Economia Brasileira : 1889-1945. 2. ${ }^{a}$ ed. Rio de Janeiro, IPEA/INPES, 1975.

VIVEIROS, Esther de. Rondon Conta Sua Vida. Rio de Janeiro, Livr. São José, 1958.

VIZENTINI, Paulo Gilberto Fagundes. Os Liberais e a Crise da República Velha. (Tudo é História, 67). São Paulo, Brasiliense, 1983. 